\title{
The Impact of External and Internal Negative Feeling on Consumers' Desire for Revenge and Negative Word of Mouth
}

\author{
Sadia Lateef ${ }^{1}$, Javeria Kamran ${ }^{1}$, Mustafa Waseem Yousuf Zai ${ }^{1}$, Marium \\ Mateen Khan ${ }^{1}$
}

\begin{abstract}
Service failure is a common problem that creates feelings of displeasure and dislike among consumers towards the service. Such feelings trigger negative word of mouth (NWOM) and desire to take revenge due to the anger and regret they feel caused by the service failure. However, seldom any research is done on these emotional aspects of service failure in Pakistan related to consumers' motivation. This study therefore has examined the effects of negative emotions on the consumer's desire for revenge and spreading of negative word of mouth by consumer who have had a bad experience using the delivery service of foodpanda. The sample size comprised of 280 participants. SPSS and SmartPLS softwares were used for analysis. PLS SEM was for hypothesis testing. The results highlighted that anger and regret had a positive and significant effect on NWOM. The study further found that anger and regret had no significant effect on the desire for revenge. Similarly, no such relationship was identified between revenge and NWOM. Likewise, there was no significant relationship between revenge and NWOM.
\end{abstract}

Keywords: negative emotions, anger, regret, revenge and negative word of mouth (NWOM), foodpanda, food delivery service.

JEL Code: M30, M31, C12

\section{Introduction}

The service industry is considered as the fastest growing industry in Pakistan. The total share of the service industry in GDP is almost 54\%, which is greater than the agricultural sector of Pakistan. With the increased technological advancement this sector aims to flourish and contribute to economic growth. This sector is also the reason for increasing employment and reducing poverty in the country (Ahmed \& Ahsan, 2011). Food and restaurant services have also been studied over the years. Past studies focused on the segments of service quality in food service, management of services, marketing of service, etc. (DiPietro, 2017).

The food delivery service market is expanding all over the globe. Restaurant meal is being served to the customers at their doorstep with the revolution of technology.

${ }^{1}$ College of Business Management (CBM), Institute of Business Management (IoBM), Karachi Sindh Pakistan

Corresponding Author: marium.mateen@iobm.edu.pk

2.PCENSS This work is Licensed under a $\frac{\text { Creative Commons Attribution-Noncommercial } 4.0 \text { International License }}{48}$ (c) () ()


Sadia Lateef et al. The Impact of External and Internal Negative Feeling on Consumers' Desire for Revenge and

Nowadays the competition is increased on the basis of services, which has also attracted large investments (McKinsey, 2011). The road and traffic conditions do not have any direct influence on the delivery services (Correa, 2019). Food delivery services are providing various models which include allowing customers to order from multiple restaurants in single order (Steever, Karwan \& Murray, 2019). According to Rathore \& Chaudhary (2018), the online delivery service has allowed customers to select their favorite food items and order conveniently. The ease provided by these services has developed the positive perception of ordering food online among the consumers.

The consumer usually buys food online only to relieve oneself from making a homecooked meal. "No need to cook" is the major reason to order food online (Tomacruz \& Flor, 2018). According to Das (2018), the factors which influenced customers to use mobile applications for ordering food are convenience, at your door step delivery process, reward systems and refund policies. Elderly people in long term care (LTC) facilities, can be affected by the delivery services (Lengyel, Zello, Berenbaum, Henry, \& Whiting, 2003), therefore such systems should work to provide variety, quality and taste in the food by examining the factors such as surroundings, results and change indicators, etc.

Digital media has provided the platform for the companies to develop good relations with the customers, this helps in increasing customer loyalty and handling of queries (Mehta, Iyer, \& Yadav, 2019). Consumer perceptions and behaviors have shown that various factors including; liking, satisfaction, preference, need, taste, quality and delivery can be used for achieving competitive advantage for companies like Zomato, Swiggy and Foodpanda, etc. (Chandrasekhar, Gupta, \& Nanda, 2019).

Foodpanda has been working in Pakistan since 2013, and has successfully emerged as one of the best online food delivery portals over the years (Tribune, 2014). Foodpanda has arranged extraordinary fun events and food tours, engaging famous bands and social media V-loggers to develop and sustain loyal fan base (Tribune, 2018). According to Dawn.com (2016) foodpanda has converted the traditional system of ordering food to something which provides consumers to pick and choose from different outlets and food providers like they do in a food court, which has helped it to increase its sales revenue. It has also signed partnerships with various famous national and international food chains to grow its business further.

Online food delivery services have faced challenges regarding price, quality and advertisements, these problems can create issues related to customers' trust and online applications' credibility (Ho, 2018). According to Simphiwe, Anne, Trilby, \& Elsamari (2012), service failures can result in generating a desire for direct and indirect revenge in the customers. Customer's reactions towards service failures can have positive and negative impact. Firms can overcome such behaviors by offering compensation or expressing regret (Joireman, Grégoire, Devezer, \& Tripp, 2013). According to Bougie, Pieters, \& Zeelenberg (2003), various emotions such as anger can create impact on customers' behavior when facing service failures. The relationship status between the 
Sadia Lateef et al. The Impact of External and Internal Negative Feeling on Consumers' Desire for Revenge and

customer and company depicts the retaliation level that can arise after service failures (Grégoire \& Fisher, 2006).

The gap in the existing literature regarding customer's behavior towards service failures in Pakistan has opened new horizons to study how negative emotions can affect consumers' desire for revenge and negative word of mouth after experiencing bad services from companies such as foodpanda. Therefore, current study will help in identifying consumer reactions resulting from encountering bad foodpanda service and up to what extent such behaviors can cause damage to foodpanda. With the help of this study foodpanda can develop strategies to cater to the customers who have suffered a bad service, eliminate bad feelings and retain those customers. This way foodpanda can further develop strong loyal customer base. Not only foodpanda but other online service industries can also identify the harm which can be caused by dissatisfied customers through this research and work on it.

Service failure is termed as any incident related to the services, either genuine or seen, amid a customer's encounter with a company (Palmer, Beggs, \&Keown-McMullan, 2000). Service failure is a common problem that creates feelings of dislike and displeasure among consumers. Such feelings trigger a negative word of mouth and a feeling of revenge due to anger and regret. Hence, Foodpanda being one of the leading food delivery services in Pakistan is often a victim of a service failure which leads to such unfavorable outcomes. A lot of research has been done in the past regarding food delivery service failures. Mueller, Palmer, Mack, \& McMullan (2003) found that $86 \%$ of the service failures were because of the service delivery system i.e. highly slow service, long wait, staff blunders, and cooking blunders. However, the element of revenge, negative WOM, regret, and anger are yet to be explored, especially in Pakistani context. Therefore, this research aims at exploring the role, revenge, negative WOM, regret and anger play in opting for food delivery service in the context of Foodpanda.

On the basis of the problem statement the research objectives for this research include; to identify whether consumers face any issues while availing the service from foodpanda, to identify whether consumers actually have desires for revenge and negative WOM after any bad experience, to identify the effect of anger on revenge, to identify the effect of anger on NWOM, to identify the impact of regret on revenge and lastly to evaluate the impact of regret on NWOM.

\section{Theoretical Underpinning and Hypotheses Development}

Anger affects revenge feelings intensely and positively. There are more chances of an aggressive person to take revenge (Ortiz et al., 2017). Yeh (2015), describes that emotional dissonance, which is conflict between feeling and feigning, builds a relation between revenge concept and customer verbal aggression. Funches (2011), recognized three causes of buyer outrage which are broken guarantees, out of line treatment and threatening vibe. He moreover, clarified in detail that buyer anger impacts past choices, repurchase behavior or shows switching behavior among consumers. Additionally, customer response to a position is mostly positive when firm ideological convictions 
Sadia Lateef et al. The Impact of External and Internal Negative Feeling on Consumers' Desire for Revenge and

are competing and buyers stay on one belief system in assertion with the manager's position, driving to less anger and way better brand states of mind (Leak, Woodham, \& McNeil, 2015).

Regret usually occurs when people feel that the results they have achieved would have been different if they had made better choices in the past (Zeelenberg \& Pieters, 2007). Regret acts as a force to influence customers' future actions. This may result in changing customers' post-purchase behavior, word of mouth and inertia (M'Barek \& Gharbi, 2012). In the case of online shopping, many factors can influence customers' regret and dissatisfaction such as poor service quality or bad information quality (Liao et al., 2011; Azemi, Ozuem, \& Howell, 2020). Any service failure will make customers disappointed, and such types of customers than regret shopping which ultimately leads to switching (Zeelenberg \& Pieters, 1999). Customers who had had any bad experience while availing any service will consider other alternatives next time. This behavior is due to the influence of regret, which allows them to silently prefer other brands instead of complaining or creating any negative word of mouth (Gilal et al., 2018; Zeelenberg \& Pieters, 2004). Feelings of disappointment and regret can also reduce consumers' satisfaction (Bui, Krishen, \& Bates, 2011; Azemi, Ozuem, \& Howell, 2020).

Word of mouth (WOM) is known as a strong driver in shaping of the attitudes of consumers. Herr et al. (1991), while Hennig et al. (2004) defined electronic word of mouth as any negative or positive statement made on the internet by former, actual or potential customers regarding a product or company. Moreover, Litvin, Goldsmith, \& Pan (2008) defined electronic word of mouth as an informal form of communication created by the consumers for the consumers regarding the use and features of a product or service and its sellers. Furthermore, negative WOM have a greater impact on consumer's mindset about a product than positive WOM (Pihlaja, Saarijärvi, Spence, \& Yrjölä, 2017). Brand loyal customers are more likely to be influenced and committed to positive WOM since it makes them feel comfortable with their brand choice. Similarly, loyal customers are less likely to notice negative WOM about their choice of brand as it moves opposite with their attitudes and beliefs and makes them mentally unstable (Gilal et al. 2018; Laczniak, DeCarlo, \& Ramaswami, 2001).

A dissatisfied customer is more likely to spread negative WOM amongst family and friends about the product or service that caused displeased (Azemi et al., 2020; Godes $\&$ Mayzlin, 2004). When a customer faces unfavorable incident related to a product or service, they are likelier to complain on social media platforms and blogging sites and hence their negative WOM becomes a threat to the apparent company (Stockman, Van Hoye, \& da Motta Veiga, 2020; Azemi et al., 2020; Svari \& Erling Olsen, 2012).

Aquino, Tripp, \& Bies (2006), characterized vindication in work environment as an exertion embraced by the casualty of hurt to cause harm, damage, distress or discipline the other party for causing the problem. Bechwati \& Morrin (2003), extended the definition of revenge desire in terms of consumer perspective as the retaliatory sentiments that customers have for any organization, such as the crave to cause harm to 
Sadia Lateef et al. The Impact of External and Internal Negative Feeling on Consumers' Desire for Revenge and

Negative Word of Mouth

(pp. 48-69)

the firm, more often after a negative bad experience. Bedi \& Schat (2017), suggested if you blame a customer it will automatically lead him to take revenge. However, if the employees empathized, the desire for revenge is minimized. On the other hand, Walsh et al. (2019) explored the positive relation between anger and revenge. They examined that consumers with higher corporate understanding and resistance levels show poorer retaliation motives than those with poor corporate understanding and lower resistance rates.

\subsection{Self Determination Theory}

Theory of self-determination (SDT) support this research. SDT was defined by Deci \& Ryan (1987) as a choices consumers make on the basis of self-motivation without the influence of psychological needs and external factors. However, Gilal et al. (2019) defined it as consumer motivation through which consumer tend to develop contingencies for their purchases and behavior. To explain the SDT in simpler words it can be said that consumers make choices either to fulfil their intrinsic or extrinsic motivation. Therefore, on the basis of SD's theoretical perspective, in this research consumer's consumer wanting to take revenge is linked with consumer's willingness to spread negative word of mouth.

Moreover, organismic integration theory (OIT), a part of SDT is the only theory as per Gilal et al. (2018) \& Gilal et al. (2020a) which has categorized and explained consumer's extrinsic motives into sub types which account for the different reasons for a specific behavior consumer engages in. e.g. in this research this theory will explain consumer's willingness to spread negative word of mouth (i.e. intrinsic regulation) because they feel wronged by the organization, in this case foodpanda (i.e. identified regulation), the consumer wants to overcome the guilt he/she feels because he/she opted for foodpanda in the first place (introjected regulation) because the consumer wants to maintain his/her status (smart buyer) in the eyes of others (external regulation).

\subsection{Hypothesis Development}

Anger is a prison that initiates negative emotions such as the desire for revenge or feelings to harm, these reactions can affect one's ease and comfort (Burdon, 2018). Anger is often seen as the trigger for seeking revenge (Aquino, Tripp, \& Bies 2006) by customers. Grégoire, Tripp, \& Legoux (2009) explained that revenge has its roots in consumer's anger. Furthermore, the revenge behavior is heightened by consumer's negative emotions they feel arising from their anger (Koo \& Ju, 2010; Grégoire et al., 2009). Breitsohl \& Garrod (2016) emphasized that among the negative emotions that a consumer feels including anger, disgust and disregard, anger is the emotion that leads to certain behavioral intentions and action in consumers. Therefore, it is hypothesized that:

$\mathrm{H}_{1}$ : There is a statistically significant and positive effect of Consumer anger on the desire for revenge. 
Sadia Lateef et al. The Impact of External and Internal Negative Feeling on Consumers' Desire for Revenge and

Negative Word of Mouth

(pp. 48-69)

Researchers suggest that anger results in wanting revenge because this act provides a sense of protection and satisfaction among the consumers (Hall, 2013). Grégoire et al. (2009), states that wanting revenge is the consequence of one's anger. Revenge is more self-focused than anger because it allows a person to harm others to get self-restoration (Elshout et al., 2015). Another study, indicates that anger and regret in consumers result in retaliatory behaviors (Bonifield \& Cole, 2007; Wen-Hai, Yuan, Liu, \& Fang, 2019). Consumers who had to face service failure engaged in spreading more negative word of mouth as a means of revenge due to their heightened sense of regret (Kim, 2016). In the view of above studies following hypothesis have been derived:

$\mathrm{H}_{2}$ : There is a statistically significant and positive effect of Consumer regret on the desire for revenge.

After any service failure, both anger and regret have a significant effect in triggering retaliatory behaviors in the form of NWOM (Bonifield \& Cole, 2007). It has also been studied that those consumers' who possess good corporate understanding will show a positive relation between anger and revenge (Walsh et al., 2019). Mostly displeasure and disappointment result in increasing NWOM in the consumers (Godes \& Mayzlin, 2004). Unfavorable services experiences and consumptions often lead towards the generation of negative emotions including anger, frustration, sadness, fear and shame, the outcome of these emotions leads the consumer towards spreading of negative word of mouth (Tronvoll, 2011). Consumers prefer to complain in the form of NWOM on social media platforms after facing any service failure to overcome their anger and regret. The feeling of taking revenge will allow them to stop others to buy from the same company (Svari et al., 2012; Wen-Hai et al. 2019). Considering these past researches following hypothesis was derived:

$\mathrm{H}_{3}$ : There is a statistically significant and positive effect of Consumer anger on negative WOM

The negative word of mouth is strictly emotion driven (Schoefer \& Diamantopoulos, 2008) and that emotion mostly negative in nature including frustration, sadness, fear, anger and regret (Koo \& Ju, 2010; Grégoire et al., 2009), further regret triggers engaging in spread of negative word of mouth (Kim, 2016). Consumers who face regret tend to spread more negative word of mouth (Wu \& Wang, 2017). Service failure faced by consumers heightens the sense of regret in consumers which triggers them to spread negative word of mouth about the service and the service provider (Kim, 2016). Therefore, it was hypothesized that:

$\mathrm{H}_{4}$ : There is a statistically significant and positive effect of Consumer regret on negative WOM

Mistreatment or failure of services create a form of aggression among customers and research shows that customers feeling aggression due to mistreatment and service failure often experience negative thoughts (Dallimore et al., 2007) i.e. wanting to harm 
Sadia Lateef et al. The Impact of External and Internal Negative Feeling on Consumers' Desire for Revenge and Negative Word of Mouth

the service provider by spreading negative word of mouth. Wen-Hai et al., (2019) found that desire for revenge is intensely related to a consumer's willingness to spread negative word of mouth. Further anger of consumers leads to desire for revenge which in turn result in different vengeful behaviors, one of which is spreading of negative word of mouth (Grégoire et al., 2009; Wen-Hai et al., 2019). Therefore, it was hypothesized that:

$\mathrm{H}_{5}$ : There is a statistically significant and positive effect of Consumer desire for revenge on negative WOM

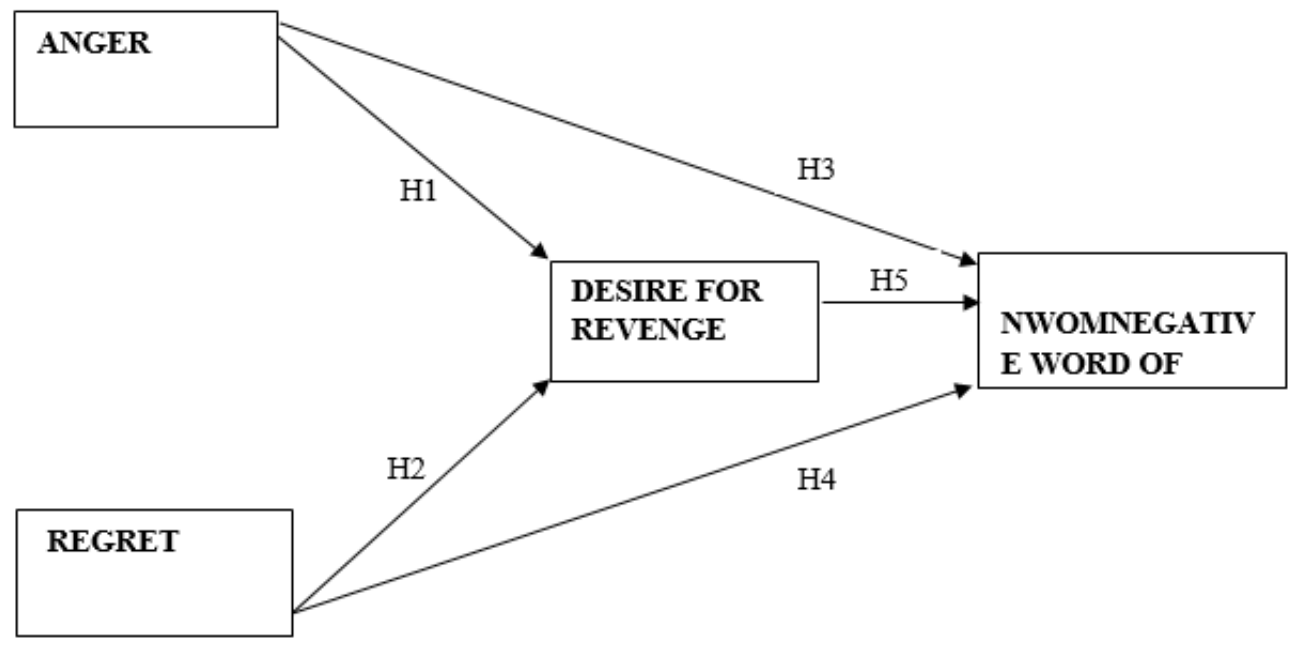

Figure 1 Conceptual framework is adopted from Wen-Hai, Yuan, Liu, \& Fang, 2019

\section{Research Methods}

\subsection{Procedure \& Participants}

This study was quantitative in nature and was based on the philosophy of positivism (Newman et al., 1998). The sample size of the research was based on 280 participants. The sampling method used was non probability-purposive sampling method because the data gathered was confined to those who had a bad experience with food panda (Skowronek \& Duerr, 2009).

There were two independent variables as anger and regret, one dependent variable; negative word of mouth (NWOM) and one mediation variable; consumer desire for revenge. SmartPLS software was used to analyze the relationship between these variables. While SPSS was used to perform EFA.

\subsection{Measurement}

For data collection, a survey (questionnaires) was used. The questionnaire consisted of 4 sections based on 4 variables. Variable anger consisted of 6 items which has been 
Sadia Lateef et al. The Impact of External and Internal Negative Feeling on Consumers' Desire for Revenge and

Negative Word of Mouth

(рp. 48-69)

adopted from (Bonifield \& Cole, June 2007; Bougie, Pieters, \& Zeelenberg, 2003). Regret consisted of 5 items which have been adopted from (Bonifield \& Cole, June 2007). While Negative Word of Mouth and Desire for Revenge each consisted of 5 items adopted from (Grégoire, Tripp, \& Legoux, November 2009)

For all the variables, Likert scale had been used to collect the data. Likert scale is a scale used to represent people attitude to something, starting from 1 that you strongly disagree (or dislike) to 5 strongly agree (or like). The questionnaire was made on Google forms and the questionnaire was shared on public platforms like Facebook, WhatsApp and, Instagram to reach a wider audience.

\section{Data analysis}

In this study the demographics, descriptive statistics, reliability, discriminant validity, exploratory factor analysis (EFA) and CB-SEM tests are used. SPSS software version 21 was used for demographics (frequencies), descriptive statistics and EFA. Whereas, reliability, discriminant validity, correlation and CB-SEM were analyzed using SmartPLS software.

\subsection{Results}

\subsubsection{Demographic Profile}

The demographic factors of the participants are shown in Table 1. According to the data, $48.2 \%$ of the total participants belong to the range of 21-30 years. Participants belonging to the age bracket of $31-40$ years are $16.8 \%$ of the total respondents. Only $2.1 \%$ of data is comprised of those people who are in the age group of 41-50 years. Whereas the remaining $32.9 \%$ belong to the group of less than 21 .

The qualification criteria are divided into five categories which include intermediate, Graduation, Masters, M.S/M. Phil and others. A total of 112 participants (40\%) belong to intermediate, which represents the major portion of the sample. 110 respondents $(39.3 \%)$ represent the category of graduation. Overall $13.9 \%$ of the sample belongs to Masters Category. Similarly, only $5.7 \%$ and $1.1 \%$ of the respondents are associated with M.S/M.Phil and others category.

Overall data is comprised of 117 male participants, which makes up $41.8 \%$ of the total sample. Whereas 163 participants $(58.2 \%)$ are female. The monthly income criteria are comprised of four categories, in which $84.3 \%$ of the total participants belong to the category of 41,000 and above. Which shows the major portion of the sample. 31,00040,000 category involves only $7.5 \%$ of the total respondents, which makes it the secondhighest category of the sample. The rest of the data belong to the categories of 21,000 $-30,000$ and up to 20,000 , which is $6.4 \%$ and $1.8 \%$ of the total data.

The last criterion of the demographic profile of those participants who had any bad experience while using the service of Foodpanda. According to the data all 280 respondents have faced issues while using Foodpanda. 
Sadia Lateef et al. The Impact of External and Internal Negative Feeling on Consumers' Desire for Revenge and

Table 1: Demographic Profile

\begin{tabular}{|c|c|c|c|}
\hline & & Frequency & Percent \\
\hline \multirow{5}{*}{ Age } & $21-30$ & 135 & 48.2 \\
\hline & $31-40$ & 47 & 16.8 \\
\hline & $41-50$ & 6 & 2.1 \\
\hline & Less than 21 & 92 & 32.9 \\
\hline & Total & 280 & 100 \\
\hline \multirow{6}{*}{ Qualification } & Graduation & 110 & 39.3 \\
\hline & MS/M. Phil & 16 & 5.7 \\
\hline & Masters & 39 & 13.9 \\
\hline & Other & 3 & 1.1 \\
\hline & $\begin{array}{l}\text { Up to } \\
\text { Intermediate }\end{array}$ & 112 & 40 \\
\hline & Total & 280 & 100 \\
\hline \multirow{3}{*}{ Gender } & Male & 117 & 41.8 \\
\hline & Female & 163 & 58.2 \\
\hline & Total & 280 & 100 \\
\hline \multirow{5}{*}{ Monthly Income } & $21,000-30,000$ & 18 & 6.4 \\
\hline & $31,000-40,000$ & 21 & 7.5 \\
\hline & 41,000 \& Above & 236 & 84.3 \\
\hline & Up to $-20,000$ & 5 & 1.8 \\
\hline & Total & 280 & 100 \\
\hline Bad Experience & Yes & 280 & 100 \\
\hline
\end{tabular}

\subsubsection{Descriptive Statistics}

According to the descriptive analysis, the variable Regret (Mean $=4.076, \mathrm{~S} . \mathrm{D}=0.9399$, Variance $=0.883$ ) has shown the lowest skewness $(-1.431)$, and variable Revenge (Mean $=2.038$, S.D $=1.0573$, Variance $=1.118)$ has shown the highest skewness (0.986). The kurtosis results for three items is positive while only one item has negative kurtosis. Regret $($ Mean $=4.076, \mathrm{~S} . \mathrm{D}=0.9399$, Variance $=0.883$ ) has the highest value for kurtosis (1.689), whereas NWOM $($ Mean $=3.836, \mathrm{~S}, \mathrm{D}=1.1578$, Variance $=1.340)$ has the lowest value for kurtosis (-0.100). All the variables lie in between \pm 2.5 , it is concluded that the collected data shows a normal tendency and no outliers have been found, therefore further research can be done (Hair et al., 2014).

\subsubsection{Reliability Statistics}

According to the reliability analysis Revenge has the highest reliability ( $\alpha=0.957$, $\mathrm{CR}=0.966 \mathrm{Mean}=2.038$, Variance $=0.002)$. Anger has given the lowest reliability $(\alpha$ $=0.914, \mathrm{CR}=0.933, \mathrm{M}=4.120$, Variance $=0.057)$. The output points that the reliability 
Sadia Lateef et al. The Impact of External and Internal Negative Feeling on Consumers' Desire for Revenge and Negative Word of Mouth

of all the constructs are in the acceptable range of greater than 0.7 , which represents that the data is reliable (Kimberlin \& Winterstein, 2008).

\subsubsection{Exploratory Factor Analysis (EFA)}

Principal factor analysis together with Varimax rotation was used for the respective constructs. Kaiser-Meyer-Olkin (KMO) for all the constructs is greater than the acceptable value of 0.6 (Hair et al., 2014). The Barley Test of sphericity is found to be significant $\mathrm{P}<0.05$. The AVE of all the constructs is higher than the value of 0.70 , which is larger than the acceptable value of 0.05 , this demonstrates the convergent validity of all the constructs (Hair et al. 2012).

Table 2: Exploratory Factor Analysis (EFA)

\begin{tabular}{|l|c|c|c|c|}
\hline Construct & Original Items & $\begin{array}{c}\text { Kaiser- } \\
\text { Meyer-Olkin }\end{array}$ & $\begin{array}{c}\text { Bartlett's } \\
\text { Test of } \\
\text { Sphericity } \\
(\mathrm{P}<0.05)\end{array}$ & $\begin{array}{c}\text { Cumulative } \\
\text { factor loading } \\
\%\end{array}$ \\
\hline Anger & 6 & .888 & 1120.135 & 70.096 \\
\hline Regret & 5 & .839 & 1329.619 & 81.392 \\
\hline Revenge & 5 & .895 & 1523.196 & 85.226 \\
\hline NWOM & 5 & .891 & 1521.602 & 84.711 \\
\hline
\end{tabular}

\subsubsection{Convergent Validity}

Based on the values of composite reliability $(\geq 0.70)$ and AVE values $(\geq 0.5)$ for each variable it is safe to say that convergent validity exists in the data used for this research.

Table 3: Convergent Validity

\begin{tabular}{|l|c|c|c|c|c|c|}
\hline & $\begin{array}{c}\text { Cronbach's } \\
\text { Alpha }\end{array}$ & rho_A & $\begin{array}{c}\text { Composite } \\
\text { Reliability }\end{array}$ & AVE & Mean & $\begin{array}{c}\text { Std. } \\
\text { Dev. }\end{array}$ \\
\hline Anger & 0.914 & 0.924 & 0.933 & 0.701 & 4.120 & 0.8868 \\
\hline NWOM & 0.955 & 0.956 & 0.965 & 0.847 & 3.836 & 1.1578 \\
\hline Regret & 0.943 & 0.943 & 0.956 & 0.814 & 4.076 & 0.9399 \\
\hline Revenge & 0.957 & 0.983 & 0.966 & 0.851 & 2.038 & 1.0573 \\
\hline
\end{tabular}

\subsubsection{Discriminant Validity}

The values in Table 4 show the result for each factor of squares of correlation between the variables and the square root of variance. Discriminate validity is used to analyze that each variable has distinctive and unique identity or not (Hair, 2014). According to Henseler et al. (2015), the square root should be higher than the squares of the correlation of each variable. 
Sadia Lateef et al. The Impact of External and Internal Negative Feeling on Consumers' Desire for Revenge and

Table 4: Discriminant Validity

\begin{tabular}{|l|c|c|c|c|}
\hline & Anger & Regret & Revenge & NWOM \\
\hline Anger & 0.84 & & & \\
\hline Regret & 0.50 & 0.90 & & \\
\hline Revenge & 0.03 & 0.02 & 0.92 & \\
\hline NWOM & 0.56 & 0.58 & 0.02 & 0.92 \\
\hline
\end{tabular}

\subsection{Structural Equation Model}

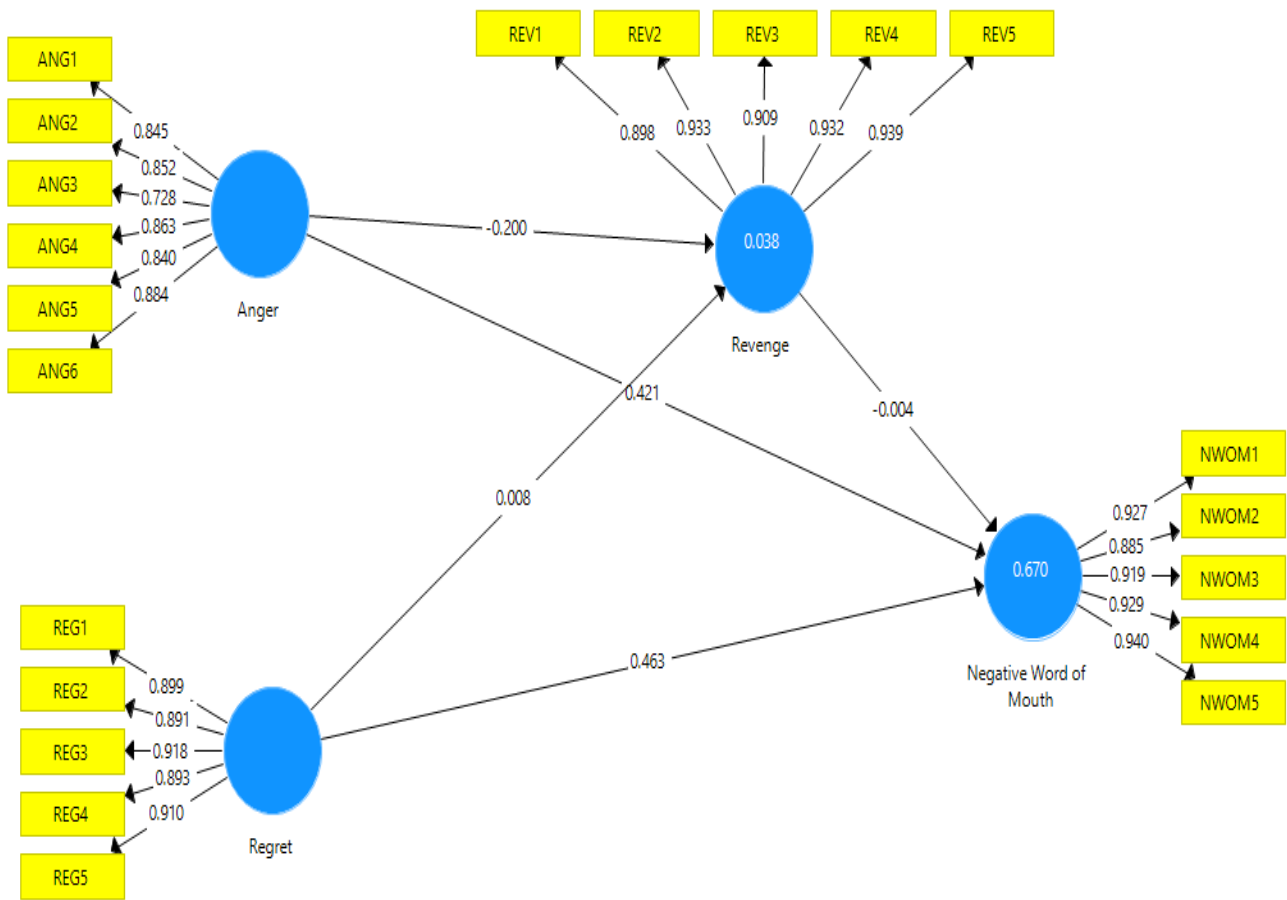

Figure 2: Measurement Model

The above measurement model is tested through SmartPLS and outputs are shown in figure 2. The results of the initial output are used to analyze the outer model measurement factors. According to the results shown in figure 2, all the items measured are above the acceptable value of 0.7 (Hair et al., 2014). This shows that there is a significant contribution of all the items to their respective constructs.

To evaluate the model fitness (Henseler, Hubona, \& Ray, 2016), examination of the saturated model and Standardized Root Mean Square Residual (SRMR) at a 95\% bootstrap quantile is done. This is valid and significant model criterion to analyze PLS 
Sadia Lateef et al. The Impact of External and Internal Negative Feeling on Consumers' Desire for Revenge and

path modeling. The value of SRMR is 0.051 , which is far below the threshold of 0.08 (Hu \& Bentler, 1999), showing that this model is fit for the study. Path coefficients of the inner model are analyzed to examine the possible linkage between the variables. For this model, the path from anger to NWOM has a strong positive coefficient 0.421 but the path form anger to revenge has the weakest correlation of negative 0.200. Considering the path of regret and NWOM, a strong positive relation of 0.463 is observed whereas in case of regret and revenge a weak relation of 0.008 is given. The path from revenge and NWOM shows a negative correlation of 0.004 . These path values are always standardized and vary from -1 to +1 . Closest values to 1 indicate strongest paths, and values closest to 0 reflect the weakest path (Garson, 2016). These results also show that anger has a much lower impact on revenge that regret. And in the case of NWOM anger has a slightly lower effect than regret.

In this model, NWOM and revenge are the two endogenous variables, with incoming variables. The value for the $\mathrm{R}^{2}$ value for the variable NWOM is 0.670 , which indicates that $67 \%$ of the variance in NWOM is due to the model. Similarly, the value of $\mathrm{R}^{2}$ for revenge is 0.038 , which means that only $3.8 \%$ of the variance in revenge is due to the combined effect of anger and regret.

To analyze the significance of the PLS coefficients, the resampling method is used through bootstrapping with the traditional PLS estimation algorithm as shown in Figure 3.

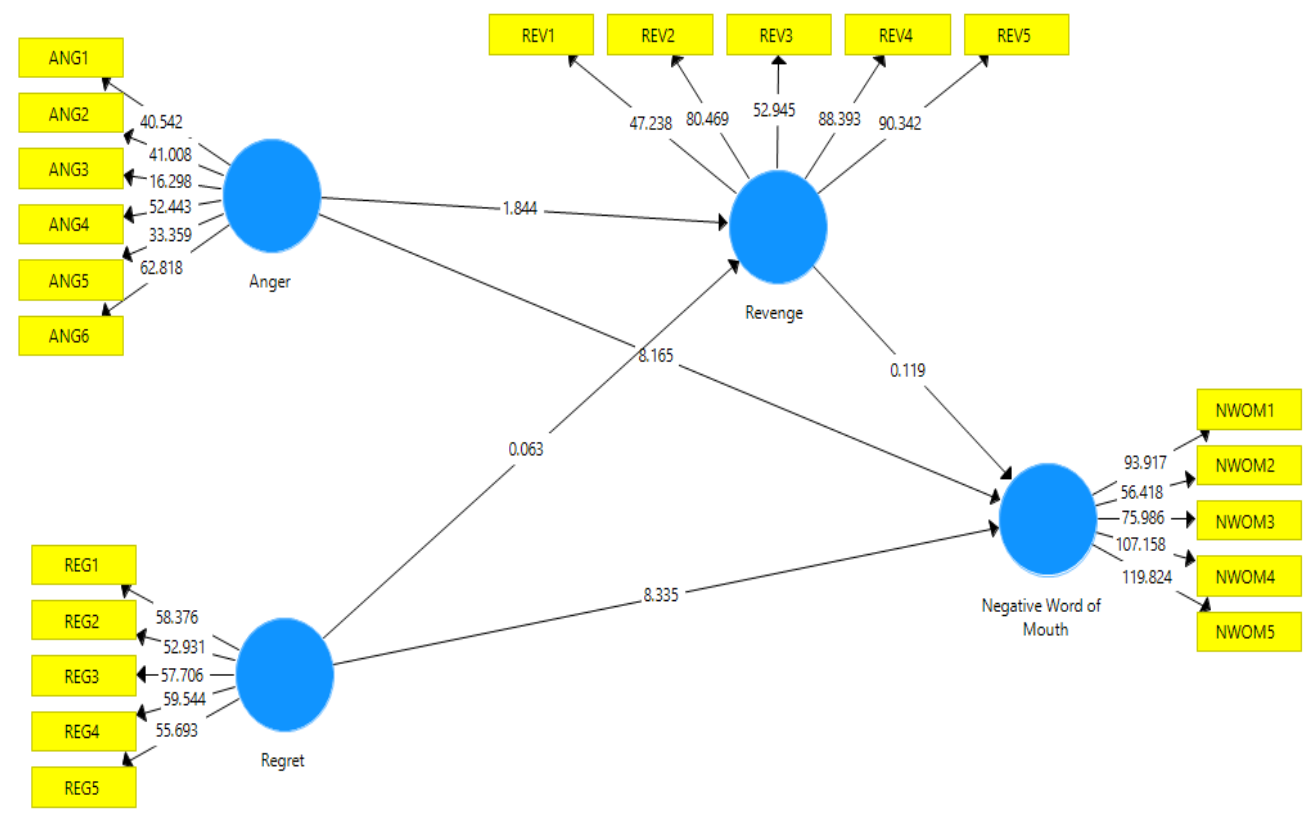

Figure 3: Structural Model 
Sadia Lateef et al. The Impact of External and Internal Negative Feeling on Consumers' Desire for Revenge and

All t-values above the threshold of 1.96 are significant at the 0.05 level (Garson, 2016). According to the output in Table 7, the $t$ value of 1.844 and $p$-value of 0.066 shows that hypothesis $1\left(\mathrm{H}_{1}\right)$ is rejected. Similarly, hypothesis $2\left(\mathrm{H}_{2}\right)$ is also rejected because of the $t$ value of 0.063 and $p$ value of 0.950 . Hypothesis $3\left(\mathrm{H}_{3}\right)$ is accepted because the observed $t$ value is far greater than $1.96(t=8.165)$ and the $\mathrm{p}$-value is at 0.00 . The fourth hypothesis of this study $\mathrm{H} 4$ is also accepted due to an increased t- value of 8.335 and $\mathrm{p}$ value of 0.00 . But again the fifth hypothesis $\mathrm{H} 5$ is rejected due to $0.119 \mathrm{t}$ value and 0.905 p-value. Overall two hypotheses $\left(\mathrm{H}_{3}\right.$ and $\left.\mathrm{H}_{4}\right)$ are accepted and three hypotheses $\left(\mathrm{H}_{1}, \mathrm{H}_{2}\right.$, and $\left.\mathrm{H}_{5}\right)$ are rejected.

The analysis of these results shows that if Anger increases then the desire for revenge decreases whereas NWOM is increased at the same time. This can due to the misinterpretation of the revenge variable. The study indicates that regret is also negatively related to the revenge variable but it also possesses a significant impact on NWOM. No significant relation has been seen between the desire for revenge and Negative word of mouth.

Table 5: T-Statistics and P Values

\begin{tabular}{|l|c|c|}
\hline & T Statistics & P Values \\
\hline Anger -> Negative Word of Mouth & 8.165 & 0.000 \\
\hline Anger -> Revenge & 1.844 & 0.066 \\
\hline Regret -> Negative Word of Mouth & 8.335 & 0.000 \\
\hline Regret -> Revenge & 0.063 & 0.950 \\
\hline Revenge -> Negative Word of Mouth & 0.119 & 0.905 \\
\hline
\end{tabular}

\section{Discussion}

This study examined five relationships between the research variables. According to the statistical study, support for the only hypothesis has been found. Below is the discussion is given about the relevance of this study with previously done researches.

The first hypothesis indicates the relationship between consumer anger and their desire for revenge. But this hypothesis was not supported by the results $(t<1.96, p>0.05)$. As per this study, consumer anger does not have any significant effect on desire for revenge. Contrary to the results, Tripp \& Bies, (2010) suggests that righteous anger has a positive relation with revenge, however, revenge has always been perceived as a response to achieve justice (Sweeney et al., 2020). Doorn (2018), defines anger as to restore any unjust situation whereas revenge means to restore oneself. Another study states that revenge behavior of any consumer can be different because of variations in the cultural background around the globe (Zourrig et al. 2009). If compared to Zourrig et al., (2009), it can be understood that revenge is considered or dealt with differently by people of a different race. Hence it can be assumed that Pakistani society may have perceived revenge as an extremely negative emotion to be used against any service failure, which has resulted in negative results of this study. 
Sadia Lateef et al. The Impact of External and Internal Negative Feeling on Consumers' Desire for Revenge and

The second hypothesis shows the relationship between consumer regret and their desire for revenge. However, this hypothesis was not supported by the results $(\mathrm{t}<1.96, \mathrm{p}$ $>0.05)$. Regret does not have any significant effect on the desire for revenge, according to the results of this study. Studies show that once the customer has achieved the emotional level of deception, the customer has a desire for revenge and avoidance, but mostly the customer depends on a desire to avoid it because a desire for revenge entails significant psychological costs (Lee et al., 2013). Good-relationship-quality customers are more likely to ignore the negative behavior than bad-relationship-quality customers, even if they regret the buying decision they are less likely to seek revenge (Grégoire et al., 2009; Sweeney et al., 2020). The desire for revenge is hard to sustain and appears to decline over time. Usually revenge is not the key factor in the eyes of customers to activate grudge or anger. Consumers' desire for conciliation is greater than the desire for revenge. As consumer looks forward to receive an apology or compensation from a brand (Joireman et al., 2013; Voorhees et al., 2017).These studies are relevant to the results of this study that the consumers' regret cannot effect revenge.

The third hypothesis states that the customer anger affects NWOM positively. This hypothesis has been supported by the research outputs $(\mathrm{t}>1.96, \mathrm{p}<0.05)$. Consumers who are angry, frustrated or irritated can spread Negative word of mouth to take revenge on the business (Wetzer, Zeelenberg, \& Pieters, 2007). Anger is a catalyst in the relationship between crisis transparency and NWOM (Coombs \& Holladay, 2007). Unhappy customers will probably switch the provider because of a service failure, complain and/or cause the spread of NWOM (Sánchez-García \& Currás-Pérez, 2011). Consumers who have had a bad experience with an organization are more driven to vent their anger, through WOM soon after the incident than those with positive experiences (Sweeney et al., 2005; Sweeney et al., 2020). With these studies, it has been suggested that anger affects NWOM.

The fourth hypothesis states that consumer regret affects NWOM positively. As per the results, this hypothesis has been accepted $(\mathrm{t}>1.96, \mathrm{p}<0.05)$. If consumer's face regret they are more into spreading negative WOM about their experience. The study done by (Wu \& Wang, 2017) presented that those consumers who blame others for their regret tend to spread more NWOM than those who experience self-blame regret. The study conducted by Wen-Hai et al. (2019) on Hunghwa Telecom Company showed a strong and positive relationship between regret and negative WOM. Another study done by (Zeelenberg \& Pieters, 2007; Sweeney et al. 2020) explored that disappointed consumers engage themselves in NWOM just to warn others, while consumers who experience regret talk to others to warn them to reinforce social bonds. Consequently, the results of this study are relevant to the literature mentioned above.

With the fifth hypothesis, this study relates consumer desire for revenge and NWOM. However, the results derived from the study have not supported this hypothesis $(\mathrm{t}<$ $1.96, \mathrm{p}>0.05)$. With this study, it resulted that the desire for revenge and negative WOM are not related. The study of (Wen-Hai et al., 2019) showed however, an effective relationship between negative WOM and desire for revenge when they conducted a 
Sadia Lateef et al. The Impact of External and Internal Negative Feeling on Consumers' Desire for Revenge and

Negative Word of Mouth

(рp. 48-69)

study in Huanghwa Telecom Company about their employees' experience. Zeelenberg \& Pieters (2007) \& Jackson, Choi, \& Gelfand, (2019) showed a positive relation, the results reveal that consumers who experience anger engage themselves in negative WOM to take revenge. The above studies support a relationship between the desire for revenge and negative WOM whereas, this study does not support a relation between revenge and negative WOM.

\section{Implications for Theory}

A lot of attention has been paid towards the research of negative word of mouth WenHai et al., 2019; Jackson et al., 2019; Voorhees et al., 2017; Sweeney, 2020), however, this research has explored the Pakistani food delivery market for the phenomenon of spreading negative word of mouth triggered due to consumer's anger, regret and desire to seek out revenge on the party that has mistreated them. Moreover, this research advances by researching the intrinsic and extrinsic motivators for spreading negative word of mouth in the light of self-determination theory (Gilal et al., 2019; Gilal et al., 2020c), in the light of self-determination theory this research suggests that the consumer's intrinsic motivators play a vital role in shaping their desire to seek revenge and spread negative word of mouth about a food delivery service which they consider has mistreated them and harmed them in any way (psychologically, financially, physically).

\section{Implications for Practice}

There can be several implications for the company foodpanda. But according to the results of this study, managers and policymakers must try to develop an effective system for the customers to register their complaints. This may help the company to solve the issues before the customers spread negative word of mouth. It should also be a matter of concern for Foodpanda that what factors are resulting in making customers angry. Therefore, the analysis of such factors (such as late delivery, poor quality or cold food) and solving such issues can help the company in reducing customer's aggression. Moreover, policymakers should focus on regular evaluation (quarterly, half-yearly or yearly) of the restaurants who fail to perform well. Such steps will help the company to get rid of those restaurants who lack skills, standards, and competency.

\section{Limitations and Future Research Directions}

This study has some limitations. First of all, this study considered the negative emotions to identify consumers' desire for revenge and NWOM. However other factors can also play an important role in influencing consumers' decisions. For instance, demographics might play a role in differences in opinions about negative word of mouth, gender differences, males and females may have differing viewpoints (Gilal et al. (2020b), online environmental cues along with the mediating effect of trust and perceived risk can also change consumers' purchase intention (Hsin Chang \& Wen Chen, 2008). Similarly, habits can also be effective in altering the behavior of consumers (Limayem et al., 2007). Moreover, moderating effects of gender and age can alos play an important role in shaping consumer's extrinsic motivation. Therefore, further studies on this topic should consider such factors into account. 
Sadia Lateef et al. The Impact of External and Internal Negative Feeling on Consumers' Desire for Revenge and

Negative Word of Mouth

(рp. 48-69)

Secondly, this study is based on a sample of 280 participants, who had any bad experience while using foodpanda. Other companies' users were not involved. Therefore, the results and findings cannot be generalized for the service failure of other companies.

Thirdly the variables chosen for the study such as the desire for revenge were considered as an extreme action against foodpanda in Pakistan. Therefore, the societal understanding of the variables should be identified for the implication of the study.

\section{Conclusion}

In this study, we have examined the effects of external and internal factors i.e. anger and revenge on the consumer's desire for revenge and regret. It has also investigated the mediating relation of desire for revenge. The results analyzed have shown no such importance of the variable revenge. However, a negative word of mouth (NWOM) has played a crucial role in interpreting that consumers' anger and regret have strong and positive relations with NWOM.

The first variable of this study is anger, which is defined to start by any triggering event which converts usual arouser in anger (Felgoise et al., 2006). In the case of consumer behavior, any service failure can result in precipitating consumer anger (Bougie et al., 2003). Similarly, this study also proves that service failure by any company can result in activating consumer anger, which can be harmful to the companies in many ways. The second variable discussed in this study is the consumer's regret. Marcel, Zeelenberg \& Pieters (2004), states that regret arises when people think that the output gained can be different when altering past choices. Regret act as a force to change consumers' future actions (M'Barek \& Gharbi, 2012). Our study identifies that regret can result in generating negative actions such as NWOM. These actions can result in reducing the overall company's reputation and customers' trust(Bui et al., 2011). The third variable of this study is revenge, Aquino et al. (2006), states that revenge is any action taken against the party that has caused any harm. Simphiwe et al. (2012) suggest that any service failure can result in indirect or direct revenge by the consumers. But this study identifies that revenge cannot be triggered by anger and regret. This can be due to the misinterpretation of the variable revenge by the respective sample of the research. Moreover, the last variable is a NWOM, is considered as an important factor in expressing consumers' regret and anger. As per the analysis, this has been identified that in Pakistan, online food delivery services such as foodpanda can initiate anger and regret in consumers due to any service failure which can result in NWOM on social media platforms. However, revenge is not considered to be the reason for such outcomes. Therefore, companies should work to manage customers' anger through effective solutions, which can help them in preventing NWOM.

\section{Author Contribution}

Sadia Lateef: Abstract, Keywords, Introduction, part of literature, data collection, Interpretation

Javeria Kamran: Part of literature, Conclusion, Recommendations, Data collection Sukkur IBA Journal of Management and Business - SIJMB | Vol 8 No. 1 January - June 2021 
Sadia Lateef et al. The Impact of External and Internal Negative Feeling on Consumers' Desire for Revenge and

Negative Word of Mouth

(pp. 48-69)

Mustafa Waseem Yousuf Zai: Methodology, Part of literature, Data collection

Marium Mateen Khan: Problem statement, Data Analysis, Part of Literature, Discussion

\section{DATA AVAILABILTY STATEMENT}

The data used in this research is primary data, collected from consumers. The data is available with the researchers.

\section{CONFLICT OF INTEREST}

No conflict of interest

FUNDING

No funding taken from anyone.

\section{REFERENCES}

Ahmed, A., \& Ahsan, H. (2011). Contribution of services sector in the economy of Pakistan. Working Papers \& Research Reports, 2011.

Aquino, K. F., Tripp, T. M., \& Bies, R. J. (2006). Getting even or moving on? Power, procedural justice, and types of offense as predictors of revenge, forgiveness, reconciliation, and avoidance in organizations. The Journal of Applied Psychology, 91(3), 653-668. https://doi.org/10.1037/0021-9010.91.3.653

Azemi, Y., Ozuem, W., \& Howell, K. E. (2020). The effects of online negative word-of-mouth on dissatisfied customers: A frustration-aggression perspective. Psychology \& Marketing, 37(4), 564-577.

Bechwati, N. N., \& Morrin, M. (2003). Outraged Consumers: Getting Even at the Expense of Getting a Good Deal. Journal of Consumer Psychology, 13(4), 440-453. https://doi.org/10.1207/S15327663JCP1304_11

Bedi, A., \& Schat, A. C. H. (2017). Employee revenge against uncivil customers. Journal of Services Marketing, 31(6), 636-649. https://doi.org/10.1108/JSM-01-2016-0003

Bonifield, C., \& Cole, C. (2007). Affective responses to service failure: Anger, regret, and retaliatory versus conciliatory responses. Marketing Letters, 18(1-2), 85-99. https://doi.org/10.1007/s11002-006-9006-6

Bougie, R., Pieters, R., \& Zeelenberg, M. (2003). Angry Customers don't Come Back, They Get Back: The Experience and Behavioral Implications of Anger and Dissatisfaction in Services. Journal of the Academy of Marketing Science, 31(4), 377-393. https://doi.org/10.1177/0092070303254412

Breitsohl, J., \& Garrod, B. (2016). Assessing tourists' cognitive, emotional and behavioural reactions to an unethical destination incident. Tourism Management, 54(20), 209-220.

Bui, M., Krishen, A. S., \& Bates, K. (2011). Modeling regret effects on consumer post-purchase decisions. European Journal of Marketing, 45(7/8), 1068-1090. https://doi.org/10.1108/03090561111137615

Burdon, E. S. (2018, May 26). How to Handle Anger And Revenge. Retrieved November 28, 2019, from Medium website: https://medium.com/pursuing-progress/how-to-handleanger-and-revenge-2b1e1b975a5c

Correa, J. C., Garzón, W., Brooker, P., Sakarkar, G., Carranza, S. A., Yunado, L., \& Rincón, A. (2019). Evaluation of collaborative consumption of food delivery services through web 
Sadia Lateef et al. The Impact of External and Internal Negative Feeling on Consumers' Desire for Revenge and

mining techniques. Journal of Retailing and Consumer Services, 46, 45-50. https://doi.org/10.1016/j.jretconser.2018.05.002

Dallimore, K. S., Sparks, B. A., \& Butcher, K. (2007). The influence of angry customer outbursts on service providers' facial displays and affective states. Journal of Service Research, 10(1), 78-92.

Das, J. (2018). Consumer perception towards 'online food ordering and delivery services': An empirical study. Journal of Management, 5(5), 155-163.

Dawn.Com. (2016, September 3). Foodpanda generates additional Rs1bn for Pakistan\&\#39;s food delivery market. Retrieved October 18, 2019, from DAWN.COM website: http://www.dawn.com/news/1281787

DiPietro, R. (2017). Restaurant and foodservice research: A critical reflection behind and an optimistic look ahead. International Journal of Contemporary Hospitality Management, 29(4), 1203-1234. https://doi.org/10.1108/IJCHM-01-2016-0046

Elshout, M., Nelissen, R. M. A., \& van Beest, I. (2015). Vengeance is self-focused: Comparing vengeful to anger-driven responses. Cognition and Emotion, 29(7), 1239-1255. https://doi.org/10.1080/02699931.2014.976181

Felgoise, S., Nezu, A. M., Nezu, C. M., \& Reinecke, M. A. (2006). Encyclopedia of Cognitive Behavior Therapy. Springer Science \& Business Media.

Funches, V. (2011). The consumer anger phenomena: Causes and consequences. Journal of Services Marketing, 25(6), 420-428. https://doi.org/10.1108/08876041111161014

Garson, G. D. (2016). Partial Least Squares. 262.

Gilal, F. G., Zhang, J., Gilal, N. G., \& Gilal, R. G. (2018). Integrating self-determined needs into the relationship among product design, willingness-to-pay a premium, and word-ofmouth: a cross-cultural gender-specific study. Psychology Research and Behavior Management, 11, 227-241.

Gilal, F. G., Zhang, J., Paul, J., \& Gilal, N. G. (2019). The role of self-determination theory in marketing science: An integrative review and agenda for research. European Management Journal, 37(1), 29-44.

Gilal, F. G., Zhang, J., Gilal, R. G., \& Gilal, N. G. (2020a). Linking motivational regulation to brand passion in a moderated model of customer gender and age: an organismic integration theory perspective. Review of Managerial Science, 14(1), 87-113.

Gilal, F. G., Gilal, N. G., Tariq, B., Gilal, R. G., Gilal, R. G., Gong, Z., \& Channa, N. A. (2020b). Intergenerational differences in fans' motivation to watch the T20 world cup: A generation cohort theory perspective. International Journal of Sports Marketing and Sponsorship.

Gilal, F. G., Gadhi, A. K., Gilal, R. G., Gilal, N. G., Zhang, N., \& Gong, Z. (2020c). Towards an Integrated Model of Customer Religiosity: A Self-Determination Theory Perspective. Central European Management Journal, 28(1), 16-37.

Godes, D., \& Mayzlin, D. (2004). Using Online Conversations to Study Word-of-Mouth Communication. Marketing Science, 23(4), 545-560. https://doi.org/10.1287/mksc.1040.0071

Greener, S. (2008). Business research methods.

Grégoire, Y., \& Fisher, R. J. (2006). The effects of relationship quality on customer retaliation. Marketing Letters, 17(1), 31-46. https://doi.org/10.1007/s11002-006-3796-4

Grégoire, Y., Tripp, T. M., \& Legoux, R. (2009). When Customer Love Turns into Lasting Hate:The Effects of Relationship Strength and Time on Customer Revenge and Avoidance. https://doi.org/10.1509/jmkg.73.6.18

Hair, Joe F., Sarstedt, M., Ringle, C. M., \& Mena, J. A. (2012). An assessment of the use of partial least squares structural equation modeling in marketing research. Journal of the 
Sadia Lateef et al. The Impact of External and Internal Negative Feeling on Consumers' Desire for Revenge and

Negative Word of Mouth

(рp. 48-69)

Academy of Marketing Science, 40(3), 414-433. https://doi.org/10.1007/s11747-0110261-6

Hair, Joseph F. (Ed.). (2014). Multivariate data analysis (7. ed., Pearson new internat. ed). Harlow: Pearson.

Hall, K. (2013). Revenge: Will You Feel Better? Retrieved November 28, 2019, from Psychology Today website: http://www.psychologytoday.com/blog/piecesmind/201309/revenge-will-you-feel-better

Hennig-Thurau, Thorsten, Kevin P. Gwinner, Gianfranco Walsh, and Dwayne D. Gremler (2004), Electronic Word-of-Mouth via Consumer-Opinion Platforms: What Motivates Consumers to Articulate Themselves on the Internet? Journal of Interactive Marketing, $18(1), 38-52$.

Henseler, J., Hubona, G., \& Ray, P. A. (2016). Using PLS path modeling in new technology research: Updated guidelines. Industrial Management \& Data Systems, 116(1), 2-20. https://doi.org/10.1108/IMDS-09-2015-0382

Herr, P. M., Kardes, F. R., \& Kim, J. (1991). Effects of Word-of-Mouth and Product-Attribute Information on Persuasion: An Accessibility-Diagnosticity Perspective. Journal of Consumer Research, 17(4), 454.

Hsin Chang, H., \& Wen Chen, S. (2008). The impact of online store environment cues on purchase intention: Trust and perceived risk as a mediator. Online Information Review, 32(6), 818-841. https://doi.org/10.1108/14684520810923953

Hu, L., \& Bentler, P. M. (1999). Cutoff criteria for fit indexes in covariance structure analysis: Conventional criteria versus new alternatives. Structural Equation Modeling: A Multidisciplinary Journal, 6(1), 1-55. https://doi.org/10.1080/10705519909540118

Jackson, J. C., Choi, V. K., \& Gelfand, M. J. (2019). Revenge: A multilevel review and synthesis. Annual Review of Psychology, 70, 319-345.

Joireman, J., Grégoire, Y., Devezer, B., \& Tripp, T. M. (2013). When do customers offer firms a "second chance" following a double deviation? The impact of inferred firm motives on customer revenge and reconciliation. Journal of Retailing, 89(3), 315-337. https://doi.org/10.1016/j.jretai.2013.03.002

Kim, S. Y. (2016). Negative word of mouth intentions during self-service technology failures: The mediating role of regret. Journal of Service Science Research, 8(1), 4155. doi:10.1007/s12927-016-0002-y

Kimberlin, C. L., \& Winterstein, A. G. (2008). Validity and reliability of measurement instruments used in research. American Journal of Health-System Pharmacy, 65(23), 2276-2284. https://doi.org/10.2146/ajhp070364

Laczniak, R. N., DeCarlo, T. E., \& Ramaswami, S. N. (2001). Consumers' Responses to Negative Word-of-Mouth Communication: An Attribution Theory Perspective. Journal of Consumer Psychology, 11(1), 57-73. https://doi.org/10.1207/S15327663JCP1101_5

Leak, R. L., Woodham, O. P., \& McNeil, K. R. (2015). Speaking candidly: How managers' political stances affect consumers' brand attitudes. Journal of Product \& Brand Management, 24(5), 494-503. https://doi.org/10.1108/JPBM-08-2014-0693

Lee, J.-S., Pan, S., \& Tsai, H. (2013). Examining perceived betrayal, desire for revenge and avoidance, and the moderating effect of relational benefits. International Journal of Hospitality Management, 32, 80-90. https://doi.org/10.1016/j.ijhm.2012.04.006

Lengyel, C. O., Zello, G. A., Berenbaum, S. L., Henry, C. J., \& Whiting, S. J. (2003). A Model for Food Service Delivery and Quality of Life in Long-Term Care Facilities. In M. J. Sirgy, D. Rahtz, \& A. C. Samli (Eds.), Advances in Quality-of-Life Theory and Research (pp. 3-12). https://doi.org/10.1007/978-94-017-0387-1_1 
Sadia Lateef et al. The Impact of External and Internal Negative Feeling on Consumers' Desire for Revenge and Negative Word of Mouth

(pp. 48-69)

Liao, C., Liu, C.-C., Liu, Y.-P., To, P.-L., \& Lin, H.-N. (2011). Applying the Expectancy Disconfirmation and Regret Theories to Online Consumer Behavior. Cyberpsychology, Behavior, and Social Networking, 14(4), 241-246. https://doi.org/10.1089/cyber.2009.0236

Limayem, M., Hirt, S. G., \& Cheung, C. M. K. (2007). How Habit Limits the Predictive Power of Intention: The Case of Information Systems Continuance. MIS Quarterly, 31, 705737. https://doi.org/10.2307/25148817

Litvin, S. W., Goldsmith, R. E., \& Pan, B. (2008). Electronic word-of-mouth in hospitality and tourism management. Tourism management, 29(3), 458-468.

M'Barek, M. B., \& Gharbi, A. (2012). How Does Regret Influence Consumer's Behavior? 11.

Mehta, G., Iyer, T., \& Yadav, D. J. (2019). A study on adoption of social media by Food Ordering \& Delivering companies for successful development of Relationship Marketing. 6(2), 11.

Newman, I., Benz, C. R., \& Ridenour, P. C. S. (1998). Qualitative-quantitative Research Methodology: Exploring the Interactive Continuum. SIU Press.

Ortiz, J., Chiu, T.-S., Wen-Hai, C., \& Hsu, C.-W. (2017). Perceived justice, emotions, and behavioral intentions in the Taiwanese food and beverage industry. International Journal of Conflict Management, 28(4), 437-463. https://doi.org/10.1108/IJCMA-102016-0084

Pihlaja, J., Saarijärvi, H., Spence, M. T., \& Yrjölä, M. (2017). From electronic WOM to social EWOM: Bridging the trust deficit. Journal of Marketing Theory and Practice, 25(4), 340-356.

Rathore, S. S., \& Chaudhary, M. (2018). Consumer's Perception on Online Food Ordering. 8(4), 6.

Sánchez-García, I., \& Currás-Pérez, R. (2011). Effects of dissatisfaction in tourist services: The role of anger and regret. Tourism Management, 32(6), 1397-1406. https://doi.org/10.1016/j.tourman.2011.01.016

Schoefer, K., \& Diamantopoulos, A. (2008). The role of emotions in translating perceptions of (in) justice into postcomplaint behavioral responses. Journal of service research, 11(1), 91-103.

Simphiwe, M., Anne, M., Trilby, R., \& Elsamari, B. (2012). Customer relationship satisfaction and revenge behaviors: Examining the effects of power. African Journal of Business Management, 6(39), 10445-10457. https://doi.org/10.5897/AJBM12.953

Skowronek, D., \& Duerr, L. (2009.). The convenience of nonprobability: Survey strategies for small academic libraries | Skowronek | College \& Research Libraries News. https://doi.org/10.5860/crln.70.7.8221

Steever, Z., Karwan, M., \& Murray, C. (2019). Dynamic courier routing for a food delivery service. Computers \& Operations Research, 107, 173-188. https://doi.org/10.1016/j.cor.2019.03.008

Stockman, S., Van Hoye, G., \& da Motta Veiga, S. (2020). Negative word-of-mouth and applicant attraction: The role of employer brand equity. Journal of Vocational Behavior, 118, 103368. (InPress)

Svari, S., \& Erling Olsen, L. (2012). The role of emotions in customer complaint behaviors. International Journal of Quality and Service Sciences, 4(3), 270-282. https://doi.org/10.1108/17566691211269585

Sweeney, J., Mazzarol, T., \& Soutar, G. (2005). The Difference between Positive and Negative Word of Mouth: Emotion as a Differentiator? Broadening the Boundaries, CB 331337. Retrieved from https://research-repository.uwa.edu.au/en/publications/thedifference-between-positive-and-negative-word-of-mouth-emotio 
Sadia Lateef et al. The Impact of External and Internal Negative Feeling on Consumers' Desire for Revenge and Negative Word of Mouth

Sweeney, J., Payne, A., Frow, P., \& Liu, D. (2020). Customer Advocacy: A Distinctive Form of Word of Mouth. Journal of Service Research, 23(2), 139-155.

The changing market for food delivery | McKinsey. (2011). Retrieved October 8, 2019, from https://www.mckinsey.com/industries/technology-media-andtelecommunications/our-insights/the-changing-market-for-food-delivery

Timothy Coombs, W., \& Holladay, S. J. (2007). The negative communication dynamic: Exploring the impact of stakeholder affect on behavioral intentions. Journal of Communication Management, $\quad$ 300-312. https://doi.org/10.1108/13632540710843913

Tomacruz, M. D. G., \& Flor, N. T. (2018). Family perception and their buying behavior for home-delivered food. International Journal of Tourism Sciences, 18(4), 237-246. https://doi.org/10.1080/15980634.2018.1551308

Tribune.com.pk. (2014, August 3). Digital economy: Foodpanda eating its way into online ordering business. Retrieved October 18, 2019, from The Express Tribune website: https://tribune.com.pk/story/743795/digital-economy-foodpanda-eating-its-way-intoonline-ordering-business/

Tribune.com.pk. (2018, December 27). 2018 year in review: Wrapping up Foodpanda's success journey. Retrieved October 18, 2019, from The Express Tribune website: https://ribune.com.pk/story/1874851/4-2018-year-in-review-wrapping-upfoodpandas-success-journey/

Tripp, T. M., \& Bies, R. J. (2010). "Righteous" Anger and Revenge in the Workplace: The Fantasies, the Feuds, the Forgiveness. In M. Potegal, G. Stemmler, \& C. Spielberger (Eds.), International Handbook of Anger (pp. 413-431). https://doi.org/10.1007/9780-387-89676-2_24

Tronvoll, B. (2011). Negative emotions and their effect on customer complaint behavior. Journal of Service Management, 22(1), 111-134.

van Doorn, J. (2018). Anger, Feelings of Revenge, and Hate. Emotion Review, 10(4), 321-322. https://doi.org/10.1177/1754073918783260

Voorhees, C. M., Fombelle, P. W., Gregoire, Y., Bone, S., Gustafsson, A., Sousa, R., \& Walkowiak, T. (2017). Service encounters, experiences and the customer journey: Defining the field and a call to expand our lens. Journal of Business Research, 79, 269280.

Walsh, G., Deseniss, A., Ivens, S., \& Schaarschmidt, M. (2019). Buffering the service failureinduced effect of anger on revenge. Kybernetes, ahead-of-print(ahead-of-print). https://doi.org/10.1108/K-01-2019-0071

Wen-Hai, C., Yuan, C.-Y., Liu, M.-T., \& Fang, J.-F. (2019). The effects of outward and inward negative emotions on consumers' desire for revenge and negative word of mouth. Online Information Review, 43(5), 818-841. https://doi.org/10.1108/OIR-03-20160069

Wu, R., \& Wang, C. L. (2017). The asymmetric impact of other-blame regret versus self-blame regret on negative word of mouth: Empirical evidence from China. European Journal of Marketing, 51(11-12), 1799-1816. https://doi.org/10.1108/EJM-06-2015-0322

Yeh, C.-W. (2015). Linking customer verbal aggression and service sabotage. Journal of Service Theory and Practice, 25(6), 877-896. https://doi.org/10.1108/JSTP-07-2014-0146

Zeelenberg, M, \& Pieters, R. (2007). A Theory of Regret Regulation 1.0. Journal of Consumer Psychology, 17(1), 3-18. https://doi.org/10.1207/s15327663jcp1701_3

Zeelenberg, Marcel, \& Pieters, R. (1999). Comparing Service Delivery to What Might Have Been: Behavioral Responses to Regret and Disappointment. Journal of Service Research, 2(1), 86-97. https://doi.org/10.1177/109467059921007 
Sadia Lateef et al. The Impact of External and Internal Negative Feeling on Consumers' Desire for Revenge and

Negative Word of Mouth

Zeelenberg, Marcel, \& Pieters, R. (2004). Beyond valence in customer dissatisfaction. Journal of Business Research, 57(4), 445-455. https://doi.org/10.1016/S0148-2963(02)002783

Zourrig, H., Chebat, J.-C., \& Toffoli, R. (2009). Consumer revenge behavior: A cross-cultural perspective. Journal of Business Research, 62(10), 995-1001. https://doi.org/10.1016/j.jbusres.2008.08.006 